821.161.1.09(497.11)

821.163.41.09

https://doi.org/10.18485/mks_srpska_slavistika.2018.2.ch22

\author{
Александар Н. ПЕТРОВ* \\ Универзитет у Питсбургу \\ Институт за књижевност и уметност у Београду
}

\title{
БЕОГРАД КАО КУЛТУРНИ ЦЕНТАР РУСКЕ ЕМИГРАЦИЈЕ И ОДНОСИ СРПСКЕ И РУСКЕ ЕМИГРАНТСКЕ КњИЖЕВНОСТИ ПРВЕ ПОЛОВИНЕ 20. ВЕКА
}

\begin{abstract}
Београд, поред Берлина, Париза, Прага, касније и Њујорка, био је значајан културни центар руске емиграције после Октобарске револуције. Руси, и представници интелигенције, осећали су се у њему као у својој другој домовини. Руски научни и књижевни живот био је веома активан, а руски научници и професори универзтета штампали су своје радове и на српском језику. Научницима и писцима млађе генерације, који су стекли образовање у Београду, или чак одбранили дкторске дисертације на Универзитету у Београду, пружале су се широке могућности за професионалну и стваралачку активност. Песници нису преводили само српску поезију на руски језик него и руску на српски, а поједини су писали стихове на српском као да им је матерњи језик. Захваљујући њима односи између српске и руске емигрантске књижевности достигли су високи ниво. Песници су и с одушевљењем писали о земљи и народу који их је дочекао раширених руку. Стихови Ј. Таубер о љубави према Београду претходе стиховима u „Ламента над Београдом” Црњанског. О срдачном односу према српском народу сведоче и писма руских значајних емигрантских стваралаца А. Белићу у вези с првим и јединим конгресом руских емигрантских писаца и новинара који је одржан у Београду 1928. године. Конгрес је према оцени свих учесника био изузетан културни и политички догађај. Захваљујући београдској издавачкој комисији, која је основана као реултата конгреса, објављен је био, као прво издање и у оригиналу, велики број књига руских писаца првога реда. И истакнутим руским писцима у Европи, а који су посећивали Београд, пружана је и материјална помоћ. Београд су и после конгреса наставили да посећују истакнути емигрантски писци из Европе. Игор Северјанин је о свом путовању по Југославији написао књигу Адриатика. У књизи сонета Медаљони, о великим руским и светским писцима и композиторима, наlази се и сонет - „Дучић”. Руски песник добро је познавао Дучићеву поезију и изгледа је преводио његове песме. Својеврсни културни феномен је представљао часопис Руски архив (1928-1937). У часопису су, мада је објављиван у Београду на српском језику, сарађивала и велика књижевна и уметничка имена (М. Цветајева, Н. Гончарова, А Ремизов, Е. Замјтин). Али је његов утицај остао ограничен због, за српску средину тог времена, противречних политичких ставова његових уредника.

Кључне речи: Руска емиграција, руски емигрантски писци и научници, руска емигрантска књижевност, Америка, „руски Берлин”, „руски Београд”, „Руска Француска”, Београд Ј. Таубер и М. Црњанског, И. Северјанин и Дучић, Конгрес руских писаца у Београду, писма руских писаца А. Белићу, комисија за издавачку делатност, Руски архив.
\end{abstract}

*sashapt@hotmail.com 
Мада се ни по броју становника, а поготово по цивилизацијском нивоу, Србија није могла упоредити са, на пример, Немачком или Француском, улога руске дијаспоре свуда у свету, па и у Србији и на Балкану уопште, била је у основи иста. С једне стране, ,сохранение и развитие русской културы в изгнании представляло собой еще одну из духовных связей беженцев с покинутой родиной (Йованович 2005: 326). А, с друге стране, „русские люди активно участвовали в научной и художественной жизни, были преподавателями, организаторами культурной жизни, выдающимся художниками, скульпторами и зодчими, как в рамках русских культурных организаций, так и в научных организациях страны, в которой они проживали (Исто: 326-327).

У Србији, посебно у Београду, нарочито је био значајан допринос руске емиграције у развоју балета и опере, али и у архитектури и низу друштвених/хуманистичких (право, историја, богословија, наука о књижевности, лингвистика) и природних наука (математика, механика и машинство, агрономија, шумарство, зоологија, геодезија, хидрологија, медицина, биологија, хемија). Преко 70 професора је радило само на Универзитету у Београду, а 11 су постали чланови Српске академије наука и уметности (Йованович 2005: 332-333).

Руски професори и научници брзо су научили српски језик и затим почели да се баве темама не само везаним за Русију, Европу и свет него и, на пример, за историју српског права и средњовековне српске државе и тој области блиске византологије. Штавише, резултате својих истраживања могли су да објављују у периодици, зборницима и ауторским књигама.

Сјај имена неких од тих научника не само да није потамнео после напуштања Русије него је наставио да светли и после доласка у Србију (П. Б. Струве, С. М. Куљбакин, Ф. В. Тарановски, Е. В. Спекторски, С. В. Тројицки и други).

Поједини професори су каријере започете или настављене у Србији с не мањим или још с већим успехом продужили касније у другим државама.

Алексеј Васиљевич Соловјев (1892-1971), правник, историчар, византолог, слависта и полиглота, стигао је у Србију као тридесетогодишњи приватни доцент универзитета из Ростова на Дону, да би четврт века на Београдском универзитету предавао историју словенског права, објављивао књиге и студије, а кратко време после Другог светског рата био и професор универзитета у Сарајеву. После политичког судског процеса крајем четрдесетих година, када је био лажно оптужен, напустио је Југославију и своју професорску и изузетну научну каријеру завршио у Женеви.

Георгиј Александрович Острогорски, мада рођен у 20. веку (1902-1976), у Србију је стигао такође у тридесетим годинама, као доктор наука и универзитетски професор, али је у Београду написао готово сва своја светски позната дела и остао је у Београду до краја живота.

За разлику од Соловјова и Острогорског, Иља Николајевич Голенишчев-Кутузов (1904-1969) и Кирил Фјодорович Тарановски (1911-1993) матурирали су и дипломирали у Београду и у југословенској престоници започели своју књижевну и научну делатност. И један и други су затим докторирали на Универзитету у Београду, били активни у београдским руским књижевним кружоцима, објављивали текстове о српској, француској (Голенишчев-Кутузов) и руској књижевности и српском стиху (Тарановски). 
Остоја Ђурић је у докторској дисертацији, касније објављеној у одличној књизи Руска литерарна Србија 1920-1941. (Писии, кружочи и издања. Београд, 1990), указао на блискост ова два значајна представника руске кретативне ителигенције.

\footnotetext{
„И једног и другог је подједнако привлачила литература, и један и други је припадао новом поколењу руских интелектуалаца, стасалом у страној земљи и свесном да се само у њој морају тражити ослонци за лична полазишта. Обојица су се слично колебали између књижевности и науке (филологије и универзитетске катедре)" (Ђурић 1990: 102-103).
}

Голенишчев-Кутузов у Паризу је сретао симболистичког песника Вјачеслава Иванова, који му је био и песнички узор. У Југославији је, поред низа других радова, објавио књигу Из нове руске књижевности 1937. године. Од средине педесетих година наставио је научну каријеру у Совјетском Савезу и у Москви је, поред других радова, нарочито о француској књижевности, штампао књигу Эпос сербского народа 1963. године.

А за Кирила Фјодоровича Тарановског др Ђурић чак тврди да се „млађи Тарановски” природније осећао „У српској неголи руској средини” (Ђурић 1990: 103). Тако је поред превода југословенске лирике на руски језик, изашла рано његова књига руске поезије на српском језику (Из руске лирике, 1927). Руски песници трудили су се и да у српској периодици што више објављују преводе својих књижевних дела. Многе руске ствараоце као да је српски језик „опијао”, а Тарановски је већ као младић од 20 година, после књиге Из руске лирике, на српски језик превео књигу песама Јесењина (Из Јесењинове лирике, 1931), затим убрзо постао вероватно најбољи преводилац руских драма на српски језик (његови преводи су често коришћени у позоришним представама), дружио се са српским писцима и чак писао и песме на српском (књига Златна мрежа, 1929). Занимљиво је да је Тарановски, који је учествовао „на приредбама младих српских песника на Новом универзиту (Студентски трг број 3)" и на другим местима, не само у Београду, свој први текст на руском језику, „Русская литература после революции” објавио у три наставка тек 1936. године (Ђурић 1990: 105).

Тарановски је у Прагу тридесетих година срео Романа Јакобсона, без чијег утицаја, као и других чланова Прашког лингвистичког круга, не би већ у својој дисертацији о руском дводелним ритмовима, одбрањеној у Београду 1941, створио дело непролазне вредности из области модерне поетике. Он је и ту своју изванредну књигу Русские двухсложные размеры. Статьи о стихе (Москва, 2010) објавио прво на српском у Београду (Руски дводелни ритмови 1953).

После доласка у Америку 1958. Кирил Тарановски је и као професор Харвардског универитета не само задржао југословенски пасош него је и често посећивао Београд. И своју чувену књигу о Мандељштаму, писану на енглеском (Essays on Mandel'štam, Cambridge, MA, Harvard U. Press, 1976) превео је сам на српски језик (Кьига о Мандељитаму, Београд 1982).

Др Ђурић је довољно простора посветио и Јелени Лоеонидовној Таубер (19031987), ћерци универзитетског професора права у Харкову, а касније и у Београду. Таубер је стигла је у Србију 1920. године као седамнаестогодишња девојка, а у Србији је завршила последња два разреда Харковског института у Србији (Нови Бечеј), у чијем се саставу налазио тада најпознатији руски институт за девојке племићког по- 
рекла Смољни. И она је била активна у руском књижевном животу у Србији, један је од преводилаца књиге Антология новой югославянской лирики (Београд 1933), ауторка пет књига песама, од којих је само прва изашла у Београду (Одиночество, 1935). Таубер је 1935. напустила Југославију, наставила да живи у Француској, а после Другог светског рата објавила је четири књиге и активно објављивала у руској емигрантској периодици. Овде истичемо њену песму „Белград”, написану пре одласка песникиње у Француску:

\section{Сергею T.}

„Ты возникаешь с крепостью старинной, В кольце двух рек спокойных и больших, Чуть озарен закатом апелсинным, Меж улочек восточных и кривых.

Ухабами ныряет мостовая,

В кофейнях песни горькие поют, Едва ползут ленивые трамваи, Газельи тени девушек снуют.

Гостеприимства город и обилья, Вдаль уходящих черепичных крыш, Ты дорог мне, как молодости крылья, В час гибели ты в сердце постучишь” (Таубер : 2002: 150).

Да би се у потпуности разумео значај ових стихова, нарочито последње строфе, требало би их сагледати у ширем контексту емиграције у руској култури и књижевности.

Изгнанство је и пре 20. века било својствено руској култури јер су, по тачном запажању Пола Таборија ,ехile and literature, Siberia and independent thought inextricably linked in Russian history" (Tabori 1972: 124).

Али Октобарска револуција 1917. и грађански рат крајем те деценије проузроковали су изгнанство битно различито од свих дотадашњих. Око 2.000.000 грађана напустило је своју државу, а и многи од оних који су остали осећали су се као изгнаници у сопственој земљи.

Двадесетвековно изгнаничко осећање изванредно је представљено стиховима Ане Ахматове: „Кто в Ташкенте, кто в Нью-Йорке / И изгнания воздух горький, / Как отравленное вино" (Ахматова 1976: 377).

Те стихове написала је песникиња која није напустила Русију, а укус отрованог вина морала је, ипак, да осети у својој домовини.

Виктор Шкловски је назвао „отровним” изгнанички хлеб, мада му је био насушан само за време кратког егзила у Берлину од априла 1922. до септембра 1923 („Но хлеб который я ел был отравлен”, Шкловский 1990: 190). А по повратку у домовину, у чланку „Смрт 'Руске Европе”” («Гибель „Русской Европы”» 1924), Виктор Борисович је тврдио, вероватно под притиском и унутрашње цензуре, да без обзира на велики број издавачких кућа и објављених књига, а и упркос томе што 
је и у емиграцији био међу веома читаним писцима, „русская наука, литература, театр, за русским рубежом не живут" (Исто).

Живела је, наравно, руска наука и уметност и ван граница Русије, мада су многи руски писци и уметници у великим европским градовима, као у Берлину и Паризу, на пример, такође осећали да удишу тај „горки ваздух изгнаства”. Зато и Шошана Дитц, када пише о руској емигрантској интелигенцији у Берлину двадесетих година 20. века, у наслову цитира Ахматову (Shoshanah Dietz: „The Bitter Air of Exile: Russian Êmigrès and the Berlin Expirience”, 1992), а у тексту наводи стихове Ходасевича и Цветајеве.

$$
\text { „Дождь убаюкивает боль” (Цветаева: „Берлину”) }
$$

\footnotetext{
„И проникая в жизнь чужую,

Вдруг с отвращеньем узнаю

Отрубленную, неживую,

Ночную голову мою” (Ходасевич: „Берлин”).
}

„Both Marina Tsvetaeva and Vladislav Khodasevich write about their Russian past, but the alienation and loss of self caused by the èmigrè experience, was revealed particularly in their poetry" (Dietz 1992: 44).

А Димитриј Сергејевич Мерешковски је „Руску Француску” („Руссофранцию”) у писму Александру Белићу описао као земљу „непријатеља, или још горе, ни непријатеља ни пријатеља” (,врагов, или хуже, ни друзей ни врагов” - в. Мрджа 2012: 95)

Када је реч о Западу, руски писци у егзилу вероватно су се једино у Америци осећали као у њима блиској средини. И то је разумљиво. Прихватљиво је тврђење Пола Таборија да се Америка може сматрати ,the classic, the most outstanding example of the cretaive exiles and 'the large-scale collective immigrations' contribution" (Tabori 1972: 155). Тачна је оцена и Едварда Саида о доприносу емиграната западној култури, а посебно Америци:

\footnotetext{
„Modern Western culture is in large part the work of exiles, émigrés, refugees. In the United States, academic, intellectual and aesthetic thought is what it is today because of refugees from fascism, communism, and other regimes given to the oppression and expulsion of dissidents" (Said 2000: 173-174).
}

Руски писци су се, и пре него што су због различитих разлога почели да стижу у Америку, нарочито уочи Другог светског рата и после његовог завршетка, и у словенским земљама, Бугарској, Чехословачкој и Југославији, посебно у Србији, осећали чак као у својој „другој домовини”.

Зато је Мерешковски у поменутом писму Белићу, а о томе сведоче и писма других руских писаца Белићу крајем двадесетих и тридесетих година, називао Југославију „земљом правих пријатеља”. Ево и целе те реченице Мерешковког, упућене Белићу после учешћа на Конгресу руских писаца у Београду 1928. године: „дня не проходит, что бы не вспоминал, здесь в земле врагов, или хуже, ни друзей ни врагов, в Руссофранции, землю настоящих друзей” (Мрджа 2012: 95-96)

Ипак, нису били ретки ни они који су двадесетих и тридесетих година напуштали словенске земље и тражили уточиште у Западној Европи. Али је знатан број остао и у тим словенским земљама све до Другог светског рата, а немали број ис- 
такнутих интелектуалаца и после доласка комуниста на власт у другој половини четрдесетих година.

Мада је и Јелена Таубер напустила Југославију пре Другог светског рата, у њеној песми „Београд” сасвим су супротна осећања у вези с Београдом него у цитираним стиховима Марине Цветајеве и Вадислава Ходасевича о Берлину. Јелена Таубер својим стиховима чак претходи неким битним стиховима једне од најбољих поема новије српске поезије, Ламенту над Београдом, коју је у изгнанству, у Енглеској, 1956. године написао Милош Црњански. Као Таубер, и српски песник слути да ће му у његовом последњем часу Београд пружити утеху:

„I kad dođe čas, da mi srce stiša,

Tvoj će bagrem pasti na me kao kiša” (Crnjanski 2010: 23)

„А кад umorno srce moje ućuti, da spi, uzglavlje meko ćeš mi, u snu, biti Ti” (Исто: 25).

Литература о „руском Берлину” је, наравно, далеко већа, него о „руском Београду”, јер је и знатно већи број руских писаца дуже или краће боравио и стварао у немачкој престоници двадесетих година и до појаве нацизма. Њихова имена су позната широм света (поред поменутих Цветајеве и Ходасевича, и Набокова, на пример) за разлику од већине руских писаца који су своју емигрантску судбину везали за Београд. А вреди упознати и њихова дела.

Београд се, чак и у односу на све друге европске градове, истакао, ипак, као организатор првог и јединог конгреса писаца руске дијаспоре. Конгрес је био одржан у Београду 1928. године, захваљујући подршци краља Александра, Српске православне цркве, професора Александра Белића, тада председника Српске академије наука и уметности, београдских власти и медија. На том изузетном скупу учествовали су многи познати руски емигрантски писци. Бобан Ћурић у својој књизи Из жизни русского Белграда наводи како су се на позив за учешће одазвала два истакнута руска писца, Мерешковски и Куприн.

„Я хорошо понимаю значение съезда не только для нас русских литераторов, но и для самого русского вопроса, а также значение благородного, бескорыстного отношения к нему сербского народа, единственного народа в Европе, для кого судьба Великой России, ее падение и возрождение - не пустые слова."

„От всего сердца приветствую прекрасную идею объединения всех писателей и защиты их прав и свобод. Я очень рад, что начинание пришло из страны, в которой всегда так сердечно относились к интересам эмигрантов и русскому искусству” (Чурич 2015: 52-53).

Изванредно је ово признање истакнутих руских емигрантских писаца српском народу. А сличан однос према српскм народу присутан је у писмима А. Белићу и других руских емигрантских писаца (в. От чужих к своим, 2016).

На конгресу су разматране разне идеје о будућим активностима руског књижевног расејања након овога скупа, а о некима од њих сазнајемо из писама која је професору Белићу након одржаног конгреса писао Ваилије Немирович Данченко (који је Србију посетио још 1876. за време српско-турског рата. Ђурић: 58). Данченко је писао да је конгрес био не само велики догађај (,событие) него и „лозунг”. 
«Лозунга великого единения для всего Российского беженства, расколовшегося на партии и поэтому до этого события бессильного в своей борьбе с большевизмом. Уже теперь здесь я вижу как этот пример подействовал на наших товарищей (не в большевистском смысле). Намечиваются пути к общим соглашениям, союзам, взаимному уважению, пакту, в котором быть может в ближайшем будущем родится одна партия, единая за Россию, за ее воскрешение. И в этом лозунге всем нам - заслуга Ваша» (Данченко 2013: 532).

А да тај огроман по значају конгрес не био постао неплодан, Данченко је настојао да се оствари Белићева идеја о издавању јединствене руске новине „для всего рассеянного русского беженства и для всего славянства, центром которого является теперь Белград" (Исто: 533).

Ова идеја о уједињавајућој руској новини, која би била објављивана баш у Београду, није ипак заживела упркос великим очекивањима руских писаца (в. Данченко 2016: 58). Други важан предлог био је да се у Београду оснује Руско-југословенска издавачка комисија. И о том амбициозном подухвату Данченко је писао Белићу, предлажући да се на руском и на српскм језику издају дела савремених руских писаца, као и дела српских писаца на два језика, затим да се прештампавају дела руских класика, јер је „в России русская дореволюционная литература почти истреблена" (Данченко 2013: 534). Данченко је чак предлагао да се у Београду издају и руски школски уџбеници и руска дечја литература.

Нису могле, наравно, у Београду да се издају књиге према програму како га је руски писац замишљао, али је учињено много, како може да се закључи према кратком наводу из књиге Русские в Югославии А. В. Мајевског.

«Издательская Комиссия, на средства югославского правительства, выпустила больше 50 книг выдающихся русских писателей: Бунина, Шмелева, Мережковского, Гиппиус, Зайцева, Чирикова, Куприна, Немировича-Данченко, Амфитеатрова и других. Неофициально, по замыслу короля Александра, целью этой Комиссии - была помощь нуждающимся русским писателям» (Маевский 1966: 22).

Све су те књиге излазиле на руском језику и то као прва издања.

Дакле, српска страна (само формално југословенска) помагала је и руским писцима који су живели не само у Србији него и у другим европским државама, знатно богатијим од Србије и Југославије. И помоћ најистакнутијим руским писцима није се састојала само у хонорарима за књиге него и у пружању редовне месечне помоћи, довољне за подмирење оних основних потреба.

И о тој помоћи налазимо податке у писмима која је Данченко упућивао Белићу.

« Глубокоуважаемый Александр Иванович.

Не нахожу слов благодарить Вас за заботу о назначении мне пенсии. Она будет как раз во время, потому что средства мои совсем истощены, хотя не думаю, что бы я пользовался ею долго» (Данченко 2015: 538).

«Еще раз не откажите Александр Иванович напомнить хоть по телефону кому следует в Вашем солнечном Белграде о злополучном пенсионере. Во сне я часто посещаю эту Дунайскую красавицу и еще вчера заснул и причудилось мне, что я стою перед усыпальницей незабвенного, великого Александра I, которого мы когда то мечтали видеть на троне воскресшей Российской Империи.. И как могли - легкомысленные союзники не уберечь такую, так необходимую и им и всем нам творческую силу! Горько думать об этом!

Искренно преданный Вам и благодарный

Вас. Немирович Данченко» (Исто: 540). 
Руски писци су долазили у Југославију и да држе књижевне вечери и предавања, а и то је био начин да им се укаже материјална помоћ. Један од њих је био је и Игор Северјанин, до Првог светког рата познат као „егофутуриста”. Северјанин је у емиграцији (остао је да живи у независној Естонији) одржавао блиску везу с руским емигрантским круговима у Београду, који су га и материјално помагали, звали у посету и омогућивали му да и у Београду објављује песме, у којима је исказивао и љубав према блиском српском народу.

У књизи с јадранским насловом (Адриатика), коју је објавио 1932. године у Естонији, Северјанин је описао у стиховима утиске о својим обиласцима разних крајева Југославије. И у насловима песама налазе се већ југословенска имена као што су Дрина, Неретва, Јадран, Дубровник, Пераст, Ловћен, Калемегдан.

А у књизи медаљона (Медальонь, Београд 1934), која садржи сто сонета о великим руским и светским песницима, писцима и композиторима, један је посвећен српском песнику чију је поезију Северјанин очигледно добро познавао, изгледа и преводио, а у неким ,јадранским” сонетиа био донекле и под његовим утицајем - „Дучић”.

„Любовь к тебе была б тебе тюрьмой:

Лишь в безграничном женщины - граница».

Как тут любить? И вот Дубровник снится,

Возникший за вспененною кормой.

Ах, этой жизни скучен ход прямой,

И так желанна сердцу небылица:

Пусть зазвучит оркестр, века немой,

Минувшим пусть заполнится страница.

«Земная дева ближе к небесам,

Чем к сердцу человеческому», - сам

Он говорит, и в истине той - рана.

Как тут любить? А если нет любви, Сверкни, мечта, и в строфах оживи

Всю царственность республики Ядрана" (Сверянин: 1934).

Северјанин, мада није живео у Југославији, вероватно је познавао српски језик довољно добро да је могао да чита Дучићеву поезију и у оригиналу.

А ваљда нигде као у Србији руска емиграција није имала такав однос према језику државе у којој се населила. За разлику од француског или немачког језика, које су многи руски интелектуалци одлично говорили, српски језик раније нису знали, а ипак су језику једног малог словенског народа посветили изузетну пажњу. Руска дијаспора у Србији као да је знањем српског језика желела да узврати на оно велико гостопримство српског народа и да српски народ, преко српског језика, што боље и више упозна с Русијом и руском културом. Ваздух Србије за њих није био као „отровано вино”, него као вино настало од грожђа руских винограда.

У том погледу један је пример готово без преседана у европском и светском контексту: руски часопис у Београду и на српском језику Руски архив. Обиман часопис (између 160 и 200 страна формата Б4) за „политику, културу и привреду” Русије, излазио је од 1928. до 1937. године, а објављена су укупно 42 броја. 
На идеолошком и културном плану издавач часописа Земгор, у писму југословенским властима (1924) Тодора Махина, касније једног од уредника Руског архива, представљен је као заступник демократије којој су подједнако туђи идеологија и пракса апсолутизма у царској Русији, следбеници те идеологије у руској емиграцији и режим комунистичке диктатуре. Парадокс је у томе што је часопис својим програмом у буржоаској и монархистичкој Југославији нудио социјалистичку алтернативу бољшевичкој Русији. Смисао часописне мисије био је, вероватно, да се циљани адресати, нарочито они левичарски настројени, одврате од стаљинистичке варијанте оновремене совјетске власти. А најзанимљивији адресати могли су да буду привучени не класичним, него модерним и авангардним вредностима оновремене руске уметности, нарочито књижевности. Такав часопис социјалдемократске усмерености није ипак био субверзиван према оновременом југословенском режиму, али га је комунистичка левица морала сматрати непријатељским.

Уредници су сматрали да је било погрешно идентификовати Русију с њеном владом и режимом, јер се тиме у први у план истицало политичко питање, а сасвим скривали Русија и њен народ. Задатак часописа био је да се лицем окрене према Русији и да прикаже целовиту и праву Русију. Часопис се разликовао од других руских емигрантских часописа и по томе што је био упућен првенствено на страног читаоца, у првом реду југословенског, па је зато излазио на српско-хрватском језику. Око часописа је био окупљен знатан број прворазредних интелектуалаца, научника, стручњака за разне области, писаца, уметника и новинара, од којих је мањи број живео у Србији и Југославији, док су остали дописе у Београд слали из Прага, Париза и других европских градова. Међу сталним сарадницима истицали су се: М. Слоним, чланцима о руским савременим писцима, Е. Стаљински текстовима о бољшевизму, др Н. Мелникова-Папушкова расправама о култури, затим познати руски писци и уметници из емиграције М. Цветајева А. Ремизов, Ј. Замјатин, Н. Гончарова, али и писци изванредних рубрика за преглед руских књига и часописа (Б. Аратов, што је био Слонимов псеудоним, С. Постников, др А. Јелачић и други). На политичком плану часопис је био привржен идеологији левог крила социјалиста револуционара, а на књижевном и уметничком подржавао је авангардну и модерну уметност у Русији, по чему се такође разликовао од већине руских емигрантских часописа (од париског Савременные записки, на пример), а и у том погледу био је близак прашком часопису Воля России.

Колико је уредницима било стало да остваре своју замисао о међусобном упознавању руске дијаспоре и српског народа, показује и објављивање књига. Тако су они зборник о Југославији (Югославия, 1930), који су писали југословенски научници, објавили на руском језику, а књигу текстова о руским писцима Марка Слонима на српском (Портрети савремених српских писаца, 1931). Слонимова књига је затим угледала свет ван Србије на руском (Портретьл советских писателей, Париж, 1933).

Жанровски разнородни прилози које часопис садржи превазилазе по вредности циљеве ондашње часописне мисије. Руски архив, због језика на којем је објављиван, припада и српском културном наслеђу, али и много ширем, нарочито руском (в. Петров 2015).

Професор Филолошког факултета Московског државног универзитета Ломоносов, Ала Шешкин, оценила је да је Руски архив „был одним из важнейших печатных органов в русском зарубежье" (Шешкин 2017: 328). 
Али је утицај Руског архива остао ограничен због противречних политичких ставова његових уредника. И то не само за српске књижевне кругове различитих књижевних и идеолошких опредељења тог времена.

Руски писци-изгнаници из Србије остали су углавном без српских следбеника. Научници сигурно нису. Један од њих, Кирил Тарановски, оставио је дубок траг. А следили су тај траг и професори на катедери за руску књижевност и језик, нарочито Миливоје Јовановић и Корнелија Ићин. Трудио се да иде стазом свог професора и старијег пријатеља и писац ових редова.

\section{Лuтература}

Ахматова А. А. „Поэма без героя.” Стихотворения и поэмы. Москва, 1976.

Ђурић О. Руска литерарна Србија. 1921-1941 (писци, кружсоии и издаюа). Београд, 1990. Ђурић О. Антология поэзии русского Белграда. Београд: Zepter Book World, 2002. Йованович М. Русская эмиграция на БАЛКАНАХ 1920-1940. Москва, 2005.

Маевский В. А. Русские в Югославии: Взаимоотношения России и Сербии. Т. II. Нью-Йорк, 1966.

Мрджа И. Письма Д. С. Мережсковского Александру Беличу. Писма Д.С. Мережсковского. Нью Йорк: Новый журнал, 2012.

Мрджа И. „Переписка Василия Немирович-Данченко с Александром Беличем.” Русское зарубежье и славянский мир. Белград, 2013.

Мрђа И. Преписка Александра Белића са руским књижевницима-емигрантима (Мерешковским, Вас. Немировић-Данченком, Бунином и Баљмонтом). Рукопис мастер рада. Београд, 2012.

От чужих к своим. Письма выдающихся представителей русской интеллигенции начала ХХ века АЛЕКСАНДРУ БЕЛИЧУ. Белград, 2016.

Петров А. Русский архив. Лицум к России в: Литературная Россия. Взгляд из Сербии. Београд, 2015a: 187-212.

Петров А. „Руски архив - часопис мисије и парадокса.” Руски архив, 1928-1937. и култура руске емигращије у Краљьвини СХС - Југославији. Београд, 2015б: $15-28$.

Северянин И. В. „Дучич.” Медальоны. Белград, 1934.

Чурич Б. Из жизни русского Белграда. Београд, 2015.

Шешкин, Алла Г., Петров А., Литературная Россия. Взгляд из Сербии. Белград, 2015. Stephanos, 2017, Москва, 6, http://stephanos.rh

Шкловский В. Б. Гамбургский счет. Москва, 1990.

Crnjanski M. „Lament nad Beogradom.” Kapor M. Crnjanski Miloš. Lament nad Beogradom. Beograd, 2010.

Dietz S. „The Bitter Air of Exile: Russian Èmigrès and the Berlin Experience.” Whitlark J., Aucock W. The Literature of Emigration and Exile, 1992. 
Said E. Reflections on Exile and Other Essays. Cambridge, 2000.

Tabori P. The Anatomy of Exile: A Semantic and Historical Study. London, 1972.

\author{
Александр Н. Петров
}

\begin{abstract}
БЕЛГРАД КАК ЦЕНТР КУЛЬТУРЫ РУССКОЙ ЭМИГРАЦИИ И ВЗАИМООТНОШЕНИЯ СЕРБСКОЙ И РУССКОЙ ЭМИГРАНТСКОЙ ЛИТЕРАТУР В ПЕРВОЙ ПОЛОВИНЕ 20 ВЕКА
\end{abstract}

\title{
Резюме
}

Белград, вместе с Берлином, Парижем, Прагой, а позже и Нью-Йорком, был одним из значительных центров культуры русской эмиграции после Октябрьской революции и Гражданской войны. Русские, включая и представителей интеллигенции, чувствовали себя в Сербии, как на своей второй родине. Литературная и научная жизнь в ,,русском Белграде” была очень активной, а русские ученые, профессора Белградского университета печатали свои труды на русском и на сербском языках. Перед учеными и писателями младшего поколения русской диаспоры, получившими образование в Сербии, в том числе, защитившими докторские диссертации в Белградском университете, открывались широкие возможности профессиональной и творческой деятелности. Поэты переводили не только сербскую поэзию на русский язык, но и русскую на сербский, писали стихи на сербском как на родном языке. Благодаря их усилиям был достигнут высокий степень русско-сербских литературных отношений. Поэты с восхищением писали о принявшей их стране; Е. Таубер с любовью писала о Белграде, как до возвращения на родину о нем писал Црнянски. Об особо близком и сердечном отношении к Сербии и к сербскому народу свидетельствуют и письма, написанные выдающимися русскими писатели-эмигрантами А. Беличу, президенту Сербской академии науки и искусства и организатору Съезда русских писателей и журналистов за рубежом, проведенного в Белграде в 1928 г. Съезд, по оценке всех участников, стал исключительным культурным и политическим событием. Его положительным результатом явилось появление Белградской издательской комиссии, которая выпустила по-русски более пятидесяти книг выдающихся писателей: Бунина, Шмелева, Мережковского, Гиппиус, Зайцева, Куприна, Немировича-Данченко и других. Сербия оказывала помощь нуждающимся русским писателям в Европе. После съезда Белград посещали многие русские писатели, жившие в разных городах Европы. Игорь Северянин написал книгу стихов о путешествии по Югославии (Адриатика). В его сборнике Медальоны о русских и мировых поэтах, писателях и композиторах, напечатанном в Белграде, один из ста сонетов посвящен сербскому поэту - «Дучич». Своеобразный культурный феномен представляет собой «Русский архив» - журнал, освещавший политику, культуру и экономику России. Журнал выходил в Белграде с 1928 по 1937 г. в двухмесячных номерах на сербском языке и был «одним из важнейших печатных органов в русском зарубежье» (А. Шешкина). М. Цветаева, Н. Гончарова, А. Ремизов, Е. Замятин своим сотрудничеством оставили неизгладимый след в «Русском архиве». Но при этом журнал не раскрыл вполне свой потенциал из-за противоречивых для сербской среды того времени политических вглядов своих редакторов.

Ключеве слова: русская эмиграция, русские писатели-эмигранты и ученые-эмигранты, литература русского зарубежья, Америка, «русский Берлин», «русский Белград», «русская Франция», Белград Е. Таубер и М. Црнянского, И. Северянин и Дучич, Съезд русских писателей в Белграде, письма русских писателей А. Беличу, издательская комиссия, Русский архив. 